\title{
COMMENTS and CORRESPONDENCE
}

\section{Announcement}

\section{Academic Freedom and Professional Responsibility after 9/11: A Handbook for Scholars}

and Teachers, prepared by the Task Force on Middle East Anthropology

Attempts to undermine professors' abilities to teach and do research are increasingly directed at scholars who seek to provide a contextualized and critical view of recent international developments and their interaction with US foreign policies and practices.

This handbook provides an overview of the range and nature of recent challenges to academic freedom. It provides concrete suggestions for how to respond to such attacks and to avoid them in the first place. Utilizing research on institutions and interviews with academics, it considers the potentials and limitations of internal university structures, professional organizations, legal recourse, and media outlets. Finally, it contains useful pedagogical tools for dealing with difficulties in the classroom, and an informative bibliography of recent writings on academic freedom.

\section{Download a copy from: www.meanthro.org}

\section{Letters}

\section{On "Israel on Trial"}

23 May 2007

To the Editor,

After reading a review essay by Rita Simon entitled "Israel on Trial" in the MESA Bulletin of December 2006 [volume 40(2): 227-229], I felt compelled to write. As a strong proponent of academic freedom, I have no problem with Zionist perspectives being expressed in the Bulletin or other MESA fora. However, such articles on any region or issue should be more substantive academically than Professor Simon's. With an opening sentence saying "The common theme in the three books under review - Finkelstein's Image and Reality of the Israel-Palestine Conflict; Ron's Frontiers and Ghettos; and Hamzeh and May's Operation Defensive Sbield - are strong anti-Israel sentiments..." (p. 227), I immediately questioned the nature of the subsequent article. It was clear that the books were not going to be dealt with on their own terms but through a political hermeneutic imposed by the reviewer and rooted in her ideological and national commitments.

This point is further validated in Professor Simon's closing line, in which she says that Finklestein, May, and Hamzeh "would have us believe that the Israelis are the Nazis of the $21^{\text {st }}$ Century. That assessment, in my view, destroys the scholarly integrity of their work" (p. 229). This last expression is 
devoid of academic merit or purpose. I hope that in the future the Bulletin includes articles based on their merit, not on the perceived need to incorporate spurious positions.

Sincerely,

Brian Wood

Professor Rita Simon stands by ber review-[Ed.]

\section{On John Wansborough}

15 July 2007

To the Editor,

In your December 2006 issue [volume 40(2):197-199], Fred M. Donner's interesting "retrospective review" of Patricia Crone and Michael Cook's Hagarism (1977) gives no credit to the late John Wansbrough for doing at least as much as them to wake up "the then rather sleepy ficld of early lslamic studies," with his enigmatic, even hermetic contributions Quranic Studies (1977) and The Sectarian Milieu (1978). In the same issue, Mohamad Nasrin misspells his name as 'Warnsbrough' in an informative but rather patronizing review of the recent reprint of Quranic Studies [pp. 250-251].

Has Wansbrough now become $a l$-ab ad, the absent one, whose name is not mentioned, or, if it is, admonishingly mangled? In any case, a thorough critical appraisal of this reputed incendiary among scholars is surely overdue.

Sincerely,

Jonathan Benthall

Honorary Research Fellow

Department of Anthropology

University College London

\section{Donner Replies}

To the Editor,

Professor Jonathan Benthall's letter rightly suggests that the late John Wansbrough, like the authors of Hagarism, offered revisionist ideas about early Islam that shook the traditional views of Islam's origins to their foundations. I did not mention his work in my review simply because that review was of Hagarism, not of all relevant recent research on early Islam. It was not meant as a slight of Wansbrough or his contribution.

I would have to differ with Prof. Benthall, however, on the relative impact of Hagarism and of Wansbrough's two books. As Prof. Benthall suggests, Wansbrough's Qur'anic Studies and The Sectarian Milieu were written in exceedingly difficult prose (he himself calls them "hermetic"). I think that, by themselves, these books would have changed a significant segment of scholarly opinion only very slowly, for the simple reason that few readers would have had the fortitude to read and digest 